\title{
Yield Potential and Vegetative Growth of Summer-planted Strawberry
}

\author{
L. Chercuitte and J.A. Sullivan ${ }^{1}$ \\ Department of Horticultural Science, University of Guelph, Guelph, Ont. N1G 2W1, Canada
}

Y.D. Desjardins and R. Bedard

Department du Phytologie, University Laval, Ste. Fey, Que. G1K 7P4, Canada

Additional inaex words. cultivar, Fragaria $\times$ ananassa, season extension, waiting-bed

\begin{abstract}
The waiting-bed (WB) system has the potential to significantly increase the length of the strawberry (Fragaria Xananassa Duch.) production season. In the WB phase of this system the plants were deblossomed and runners were removed to stimulate the production of a multiple crowned plant. The objective of this study was to examine the influence of planting date and cultivar on yield potential and vegetative growth of the strawberry plants in the WB and cropping beds (CB). Experiments were conducted in Ontario and Quebec. Early establishment of the WB favored the production of large multicrown plants. 'Kent' appeared to be the best cultivar among five tested due to the many berries produced because of good fruit set. Yield potential was not realized in late-planted CB. The highest yields per plant (273 g) were obtained in Quebec with plants from the earliest WB. Yields in CB decreased with later plantings due to stress of transplanting when air and soil temperatures were high. Berry count was identified as the yield component most affected by the later planting date of the CB. The WB system has potential for season extension in strawberry, but WB must be established early in the season to encourage the development of a plant with high yield potential.
\end{abstract}

Consumer demand for fresh strawberries after the normal Junebearing season has resulted in significant imports into Canada from July through September. The June-bearing cultivars now grown produce a single crop of fruit during early summer and do not satisfy present market demands for extended availability.

Production of out-of-season strawberries has been attempted using more heat- or cold-tolerant June-bearing cultivars (Daubeny, 1980) but this approach extended the harvest season by only 4 weeks. Generally, everbearing or day-neutral cultivars are not widely planted at northern latitudes (Galletta and Bringhurst, 1990). Recent studies conducted with day-neutral cultivars (Leblanc et al., 1987) demonstrated a high annual yield potential, but individual harvests were small and irregular and berries were smaller than observed with June-bearing cultivars. Confined production under low plastic tunnels or greenhouses is common in Europe (Daubeny, 1980), but greenhouse strawberry production in eastern Canada was considered uneconomical due to the high costs of heating (Craig and Brown, 1977). Floating row covers permit earlier harvests of strawberries but will not extend production after the June-bearing season (Daubeny, 1980).

The European WB system described by Baumann and Daubeny (1989) may have potential to extend the strawberry production season. Based on the production and cold storage of multicrown plants with high yield potential, this system permits management of the timing and quantity of harvest through control of time and amount of planting, respectively. Only the study by Baumann and Daubeny (1989) has evaluated the WB system in North America. The study was conducted in the unique (to North America) environment of the Pacific Northwest and focused on the adaptability and yield potential of four cultivars in that environment. We found no study focusing on yield com-

Received for publication 23 July 1990. This study was supported by the Ontario Ministry of Agriculture and Food and the Ontario Berry Growers Assn. We thank Simon Van Schyndel for expert technical advice. The cost of publishing this paper was defrayed in part by the payment of page charges. Under postal regulations, this paper therefore must be hereby marked advertisement solely to indicate this fact.

${ }^{1}$ To whom reprint requests should be addressed. ponents and the influence of vegetative characters that might permit further optimization of yield and quality.

The objectives of the present study were to: 1) compare the effect of planting date on vegetative growth and yield potential, and 2) evaluate the adaptability of several strawberry cultivars to summer planting using the WB system.

\section{Materials and Methods}

These studies were conducted at the Cambridge Research Station, Cambridge, Ont., and Research Farm, Laval Univ., Ste. Fey, Que., in 1985 and 1986. The WB system described by Baumann and Daubeny (1989) formed the basis for the procedures we used. Briefly, the WB system was composed of three phases: 1) cold-stored strawberry runner plants were planted at high density and intensively managed to encourage multiplecrown formation; 2) plants were dug and cold-stored, then 3) they were planted into $\mathrm{CB}$ for fruit production. In the present studies, research focused on the WB and CB phases at both locations. In addition, a greenhouse study was conducted at Laval Univ. to evaluate yield components under controlled environment conditions.

Establishing waiting-beds on four dates. WB were established on four dates (17 and 27 June, 8 and 18 July, 1985) to produce WB plants of 'Kent' strawberry. Dormant runner plants were taken from a local field of 'Kent' strawberry in Nov. 1984 and held in cold storage (at -1 to $-2 \mathrm{C}$ ) after being cleaned. At each date of planting, plants were grown in a small bed 3.0 $\times 0.3 \mathrm{~m}$ (length/width) and randomly assigned within each of five blocks. Plant spacing within each four-row bed was 0.15 $\times 0.15 \mathrm{~m}$ with 25 plants per row. The design was a randomized complete block. Plants were watered to field capacity after planting, using sprinkler irrigation, and fertilized with $500 \mathrm{ml}$ of fertilizer $(10 \mathrm{~N}-52 \mathrm{P}-10 \mathrm{~K})$ the following day. During the growing season, water and $\mathrm{N}$ fertilizer ( $34 \mathrm{~N}-0 \mathrm{P}-0 \mathrm{~K} 20 \mathrm{ppm}$ ) were applied daily by a trickle irrigation system until 30 Aug. when fertilization was stopped. Weeds were removed by hand

Abbreviations: $\mathrm{CB}$, cropping bed; CNO, crown number; CSWB, cold-stored waiting bed; FLNO, flower number; WB, waiting bed. 
when necessary. All flower trusses and runners were removed by hand as they appeared.

Establishing waiting-beds for five cultivars. The Cambridge WB were established in 1985 to produce the WB plants. Runner plants, 300 each of 'Kent', 'Micmac', and 'Raritan', were collected from a field in Simcoe, Ont., and of 'Elvira' and 'Bogata' near Campbellville, Ont., on 12 Aug. 1985. All plants were held at $5 \pm 2 \mathrm{C}$ until field-planted 2 days later.

The WB were planted by hand at the Cambridge Research Station in a four-replication randomized complete-block design. Each cultivar was randomly assigned to four WB of the same dimensions as those used at Laval. Plants were watered thoroughly by use of sprinkler irrigation after planting and daily thereafter. Granular ammonium nitrate $(34 \mathrm{~N}-0 \mathrm{P}-0 \mathrm{~K})$ and potassium nitrate $(13 \mathrm{~N}-0 \mathrm{P}-44 \mathrm{~K})$ were broadcast the following day at $25 \mathrm{~kg} \cdot \mathrm{ha}^{-1}$. Weeds were removed by hand when necessary. All flower trusses' and runners were removed by hand as they appeared.

The WB plants were dug by hand at both locations on 30 Oct. and 11 Nov. at Lava1 and Guelph, respectively, when the plants were deemed to have entered dormancy. Roots were washed and dipped in Benlate (50\% WP 333 ppm) solution before being stored in black polyethylene bags at -1 to $-2 \mathrm{C}$ until required for planting into the $\mathrm{CB}$ or greenhouse trials.

Five random plants from each replication were sampled to provide data on several growth characteristics, including crown number (CNO), crown diameter, root dry weight, number of leaves (LNO), leaf dry weight, and leaf area (at Laval only). Measurements were made 120 days after the initial planting date (17 June) at Lava1 and 89 days after planting at Cambridge.

Establishing cropping-beds on three dates. The Lava1 Univ. CB experiment was established in 1986 to compare the performance of 'Kent' plants produced in WBs established on four dates (17 and 27 June, 8 and 18 July). The plants were produced in 1985 at Lava1 Univ. during the first phase of the WB system.

The CB treatments were conducted in a four-replication randomized complete-block design. There were four WB and three $\mathrm{CB}$ treatments in a full factorial arrangement. Each WB- and CB-planting date treatment was grown in a $\mathrm{CB} 3.0 \times 0.30 \mathrm{~m}$ (length/width) and randomly assigned within each replication. Plant spacing within each two-row bed was $0.30 \times 0.30 \mathrm{~m}$ with 10 plants per row. Adjacent beds were $0.9 \mathrm{~m}$ apart. $\mathrm{CB}$ were planted on 15 May (corresponding to the usual planting date in Quebec), 16 June, and 15 July. Before being planted, plants were taken from the cold storage and allowed to reach room temperature $(\approx 15 \mathrm{C})$ during $24 \mathrm{~h}$. The July CB had only $50 \%$ of the normal plant count (i.e., 10 in two rows of five plants each) due to a shortage of plants. Water was supplied via sprinkler irrigation daily or every 2 nd day. Thirty days after planting, a side-dressing of ammonium nitrate $\left(34 \mathrm{~N}-0 \mathrm{P}-0 \mathrm{~K}, 35 \mathrm{~kg} \cdot \mathrm{ha}^{-1}\right)$ was applied to the planting.

Berries were picked and data collected on a plot basis with time and duration of harvest varying according to the date of planting. Plots were hand-picked twice weekly and berries were sorted into marketable and nonmarketable classes. Marketable fruit were defined as regularly shaped berries $>2 \mathrm{~cm}$ in diameter, and the nonmarketable class included misshapen, damaged, or small $(<2 \mathrm{~cm}$ in diameter) berries.

Establishing cropping-beds of five cultivars on four dates. Cold-stored waiting-bed (CSWB) strawberry plants, 240 each of 'Kent', 'Micmac', 'Raritan', 'Elvira', and 'Bogata', were used in this study. The Guelph CB experiment was established in 1986 to evaluate the yield potential of the five cultivars at four planting dates (8 May, 16 June, 10 July, and 1 Aug.) in the CB. These CSWB plants were produced in 1985 at Guelph from one WB planted on 14 Aug.

The CB study was conducted in a three-replication randomized complete block design with five cultivars and three planting dates in a full factorial arrangement. Each cultivar was grown in a CB $3.0 \times 0.30 \mathrm{~m}$ (length/width) and randomly assigned within each replication. Plant spacing within each two-row bed was $0.30 \times 0.30 \mathrm{~m}$ with 10 plants per row. Adjacent beds were $0.30 \mathrm{~m}$ apart. Plants were slowly brought to room temperature $(\approx 15 \mathrm{C})$ during $24 \mathrm{~h}$ before being planted. Water was supplied via sprinkler irrigation immediately after planting and then for five consecutive days per week via drip irrigation during the production season. One week after planting, $300 \mathrm{ml}$ of fertilizer (10N-52P-10K, $2 \mathrm{~g} \cdot$ liter $^{-1}$ ) was applied to the planting, followed by a side-dressing of ammonium nitrate (34N-0P-0K, $35 \mathrm{~kg} \cdot \mathrm{ha}^{-1}$ ) 2 weeks later. Ridomil 240 EC (metalaxyl 240 g-liter-') was applied to plants immediately after each of the July and August CB plantings. On 30 July, the insecticide 'Sevin' (carbaryl 50\% WP) was applied at $2.25 \mathrm{~kg} \cdot \mathrm{ha}^{-1}$ to the $\mathrm{CBs}$ for control of sap beetle [Stelidota germinata (Say)].

Thirty days after establishment, measurements on FLNO, truss number (TNO), and LNO on a per-plant basis were taken for each cultivar. Plant vigor was recorded using a 1 to 6 scale based on the number of uniform and fully expanded leaves as follows: $1=$ dead, 2 = one or two leaves, $3=$ three or four leaves, 4 = five to seven leaves, 5 = eight or nine leaves, and $6=10$ leaves or more. Berries were harvested and data collected on a plot basis with time and duration of harvests varying according to the date of planting and cultivar. By the 6th week, remaining berries were of unmarketable size, thus harvest was terminated. Plots were hand-picked twice weekly and berries were not graded. For each week of harvest, measurements were taken on berry weight and number. In addition, average berry weight and percentage aborted flowers were calculated.

Establishing a greenhouse cropping-bed. The greenhouse experiment was established on 9 Apr. 1986, to evaluate and compare the potential productivity (growth and yield) of CSWB 'Kent' strawberry plants under controlled environment conditions. The CSWB plants used for this study were taken from the fifth replication of the trials established to produce materials for the Lava1 field trials. Plants were removed from cold storage on $7 \mathrm{Apr}$. and allowed to acclimate at $\approx 15 \mathrm{C}$ for 2 days before being planted.

The design in the greenhouse was a two-replication, randomized complete block. There were four treatments in this trial consisting of the four WB planting dates previously described in the Laval WB phase. Each treatment was grown in a row of nine plants. The CSWB strawberry plants were planted in commercial $0.08 \mathrm{~m}^{3}$ plastic bags of 'Promix BX' at a plant spacing of $30 \mathrm{~cm}$ within a bag (i.e., three plants per bag). Water was supplied at the rate of 2 liters-day-' for the first 2 weeks and 4 litersday-' thereafter. One liter of a solution composed of $0.2 \mathrm{~g}$ ammonium nitrate and $0.03 \mathrm{~g}$ of chelated trace elements $\operatorname{mix}$ (B 1.3\%, Mo 0.06\%, Fe 7\%, Zn 0.4\%, Cu 0.1\%, and $\mathrm{Mn}$ $4.7 \%$ )/liter was also supplied each day using drip irrigation. No supplemental lighting was provided. The greenhouse was maintained continuously at $15 \pm 3 \mathrm{C}$ with $55 \% \pm 5 \% \mathrm{RH}$. During flowering, a 'Solo' backpack power unit with air blast attachment was used each morning to facilitate good pollination.

Fruit data were collected twice weekly during the entire 4 weeks of fruiting from 2 to 27 June and graded as marketable or nonmarketable using standards already described. 
Table 1. Analysis of variance for several yield components of summer-planted strawberry at Laval.

\begin{tabular}{|c|c|c|c|c|c|c|c|}
\hline \multirow[b]{2}{*}{$\begin{array}{l}\text { Source of } \\
\text { variation }\end{array}$} & \multicolumn{4}{|c|}{ All berries } & \multicolumn{3}{|c|}{ Marketable berries } \\
\hline & & $\begin{array}{c}\text { Yield } \\
\text { (g/plant) }\end{array}$ & No. & $\begin{array}{c}\text { Mean } \\
\text { wt } \\
\text { (g) }\end{array}$ & $\begin{array}{c}\text { Yield } \\
\text { (g/plant) }\end{array}$ & No. & $\begin{array}{c}\text { Mean } \\
\text { wt } \\
(\mathrm{g}) \\
\end{array}$ \\
\hline $\begin{array}{l}\text { ation } \\
\text { g date }\end{array}$ & 3 & 5328 & 52.7 & 042 & 4705 & 44.2 & 0.55 \\
\hline WB & 3 & 1,892 & 113 & $4.91 * *$ & 1,421 & $64.4^{* *}$ & $* 4.8$ \\
\hline $\mathrm{CB}$ & & $83,524 * *$ & $917.1 * *$ & 0.51 & $51,215 * *$ & $460.1^{* *}$ & * 0.59 \\
\hline $\mathrm{WB} \times \mathrm{CB}$ & 3 & 1,353 & 13.1 & 0.88 & 884 & 6.1 & 1.14 \\
\hline Error & 20 & 1,620 & 22.5 & 0.47 & 1,229 & 12.4 & 0.79 \\
\hline
\end{tabular}

*,**Significant at $P=0.05$ or 0.01 , respectively.

Pearson's correlation coefficients were calculated between vegetative variables (FLNO, CNO, and TNO) and yield and yield components.

Data were compared using simple regression and orthogonal contrasts where appropriate.

\section{Results}

For field trials conducted at Laval (Table 1) and Cambridge (Table 2), few interaction terms were significant, and those deemed important are discussed below.

Planting date effect. In general, earlier season establishment of WB at Laval produced larger plants with significantly higher leaf count, area, and dry weight, although the differences were not significant for all characters (Table 3 ). The plants produced in the earliest planted WB (17 June) had a leaf area $\left(2034 \mathrm{~cm}^{2} /\right.$ plant) $38 \%$ higher than the next planting date 10 days later. June plantings produced plants with more crowns $(26 \%)$ and a higher root dry weight $(35 \%)$ than July plantings.

Yield and yield components of the Laval WB plants were measured in the greenhouse and field. Berry yield and its components were affected by planting date of WB and CB (Tables 4 and 5). The 15 July planting produced no harvestable yield at Laval due to frost damage on 26 Sept. The decrease in total and marketable berry yields' as WB planting dates were later was due to a significant decrease in berry count (Table 5). For example, total berry count declined $58 \%$ and $36 \%$ in greenhouse and field trials (15 May CB), respectively, between the 17 June and 18 July WB planting dates. During the same period, berry weights increased $35 \%$ in the greenhouse and $22 \%$ in the field trials. The decline in marketable berry count was a quadratic response in both environments, with the greatest average decline
(3.8 berries or $18 \%$ ) occurring between the 17 and 27 June WB planting dates. There was no concomitant decline in berry weight. The proportion of nonmarketable berries was highest during the earliest WB planting dates only in the greenhouse trial. There was no significant change in the proportion of nonmarketable berries at either $\mathrm{CB}$ planting date in the field trial. The average reduction in yield and berry count between the 15 May and 15 June CB plantings was $105 \mathrm{~g} /$ plant and 10.9 berries per plant, respectively.

Correlation coefficients from the greenhouse trial were significant and positive for $\mathrm{CNO}$ and several other characteristics, including TNO $(r=0.74, P>0.0001)$, FLNO $(r=0.70, P$ $>0.0001)$, total yield $(r=0.60, P>0.0001)$ and total berry count $(r=0.65, P>0.0001)$. However, CNO and marketable berry weight were significantly and negatively correlated $(\mathrm{r}=$ $-0.27, P>0.0001)$.

All cultivar $\times$ CB date interaction terms for yield components measured at Cambridge were nonsignificant with the exception of mean berry weight and percentage aborted flowers, so only main effects are presented (Table 2). Yield (Table 6) and growth components (Table 7) were highest for the 8 May planting, which corresponds to a typical planting date for strawberry at Cambridge. The total yield decrease between the 8 May and 1 Aug. planting date reflected a negative linear trend. The $80 \%$ decline in yield was accompanied by a negative linear decrease in berry weight, a result also observed at Laval (Table 4). Berry weight also declined significantly between 8 May and 1 Aug. The significant interaction between CB date and cultivar for mean berry weight (Table 2) was caused by 'Kent', which had a higher berry weight $(5.4 \mathrm{~g})$ during the fourth (1 Aug.) than the second ( $4.6 \mathrm{~g})$ or third $(3.9 \mathrm{~g}) \mathrm{CB}$. In contrast, berry weight at Laval actually increased linearly as the date of establishing the $\mathrm{CB}$ was later (Table 4). At Cambridge the number of aborted flowers increased significantly between the early and late planting dates, and by 1 Aug. $70 \%$ of the flowers had not set fruit (Table 7).

Cultivar effect. Compared with the other four cultivars, 'Kent' demonstrated the greatest potential for summer planting because it was capable of producing the highest yield and berry count (Table 6). 'Raritan' performed very poorly due to its low flower count and berry weight (Table 7). Yield of 'Raritan' was about one-third that of 'Kent'. From the 8 May to 1 Aug. CB, the yield of 'Kent' was 109, 55.5, 45.8, and $44.7 \mathrm{~g} / \mathrm{plant}$, respectively. Similarly, the yield reduction between the first and second planting date at Laval was $\approx 50 \%$.

Significant differences among cultivars were measured for all

Table 2. Analysis of variance for several growth and yield components of summer-planted strawberry at Cambridge.

\begin{tabular}{|c|c|c|c|c|c|c|c|c|}
\hline \multirow[b]{3}{*}{ Source } & \multirow[b]{3}{*}{ df } & \multirow{2}{*}{\multicolumn{4}{|c|}{ Growth components }} & \multicolumn{3}{|c|}{ Yield components } \\
\hline & & & & & & \multirow{2}{*}{$\begin{array}{l}\text { Total } \\
\text { berry } \\
\text { yield } \\
\text { (g/plant) }\end{array}$} & \multirow[b]{2}{*}{$\begin{array}{c}\text { Berries/ } \\
\text { plant }\end{array}$} & \multirow{2}{*}{$\begin{array}{c}\text { Mean } \\
\text { berry } \\
\text { wt } \\
(\mathrm{g})\end{array}$} \\
\hline & & $\begin{array}{l}\text { Plant } \\
\text { vigor }\end{array}$ & $\begin{array}{c}\text { Trusses/ } \\
\text { plant }\end{array}$ & $\begin{array}{c}\text { Flower } \\
\text { no. } \\
(\% \text { set } / \text { plant })\end{array}$ & $\begin{array}{l}\text { Aborted } \\
\text { flowers } \\
\text { (\%/plant) }\end{array}$ & & & \\
\hline \multirow{2}{*}{$\begin{array}{l}\text { Replication } \\
\text { Cropping bed } \\
\text { date (D) }\end{array}$} & 2 & 0.28 & 0.49 & 36.9 & 125 & 639.7 & 12.5 & 0.74 \\
\hline & 3 & $1.19^{*}$ & 0.42 & $223.3^{* *}$ & $7,654.9^{* *}$ & $12,752.3^{* *}$ & $237.6^{* *}$ & $16.34^{*}$ \\
\hline Error & 6 & 0.15 & 0.19 & 3.3 & 31.3 & 95.2 & 0.9 & 0.22 \\
\hline Cultivar (C) & 4 & $3.23^{*}$ & $2.85^{* *}$ & $157.8 * *$ & $765.0^{* *}$ & $2,422.4^{* *}$ & $80.2^{* *}$ & $7.78^{* *}$ \\
\hline$C \times D$ & 12 & 0.21 & 0.41 & 25.2 & $221.9^{* *}$ & 295.5 & 7.4 & $2.04^{*}$ \\
\hline Error & 32 & 0.39 & 0.40 & 26.6 & 41.6 & 485.1 & 11.9 & 0.34 \\
\hline
\end{tabular}

*** Significant at $P=0.05$ or 0.01 , respectively. 
Table 3. Vegetative growth of 'Kent' strawberry runner plants established in WB on four dates at Laval.

\begin{tabular}{|c|c|c|c|c|c|c|c|}
\hline \multirow[b]{2}{*}{$\begin{array}{l}\text { Planting } \\
\text { date }\end{array}$} & \multirow{2}{*}{$\begin{array}{c}\text { Days } \\
\text { after } \\
\text { planting }\end{array}$} & \multicolumn{3}{|c|}{ Leaf } & \multicolumn{2}{|c|}{ Crown } & \multirow{2}{*}{$\begin{array}{c}\text { Root } \\
\text { dry wt } \\
(\mathrm{g}) \\
\end{array}$} \\
\hline & & No./plant & $\begin{array}{c}\text { Area } \\
\left(\mathrm{cm}^{2} / \text { plant }\right)\end{array}$ & $\begin{array}{c}\text { Dry wt } \\
(\mathrm{g})\end{array}$ & No./plant & $\begin{array}{r}\text { Diam } \\
(\mathrm{mm})\end{array}$ & \\
\hline 17 June & 120 & 16.9 & 2034 & 111.8 & 2.9 & 18 & 18.8 \\
\hline 27 June & 110 & 14.3 & 1471 & 78.3 & 2.9 & 17 & 20.0 \\
\hline 8 July & 99 & 13.6 & 1577 & 70.0 & 2.1 & 15 & 14.3 \\
\hline 18 July & 89 & 14.4 & 1346 & 71.4 & 2.5 & 16 & 14.5 \\
\hline Significance & & $\mathrm{L}, \mathrm{Q}^{* *}$ & $\mathrm{~L}, \mathrm{Q} * *$ & $\mathrm{~L}, \mathrm{Q}^{* *}$ & $\mathrm{~L}^{*}$ & $\mathrm{~L} *$ & $\mathrm{~L} * *$ \\
\hline
\end{tabular}

$*, * \$$ Linear $(\mathrm{L})$, quadratic $(\mathrm{Q})$, and significance at $P=0.05$ or 0.01 , respectively.

Table 4. Yield and yield components of greenhouse-grown cold-storage WB strawberry produced in 1985 from four WB planting dates (Laval).

\begin{tabular}{|c|c|c|c|c|c|c|c|}
\hline \multirow[b]{2}{*}{$\begin{array}{l}\text { Planting date } \\
\text { of WB }\end{array}$} & \multicolumn{3}{|c|}{ All berries } & \multicolumn{3}{|c|}{ Marketable berries } & \multirow[b]{2}{*}{$\begin{array}{c}\text { Nonmarketable } \\
\text { berries } \\
(\%) \\
\end{array}$} \\
\hline & $\begin{array}{l}\text { Yield } \\
\text { (g/plant) }\end{array}$ & No./plant & $\begin{array}{c}\text { Mean } \\
\text { wt } \\
(\mathrm{g}) \\
\end{array}$ & $\begin{array}{l}\begin{array}{l}\text { Yield } \\
\text { (g/plant) }\end{array} \\
\end{array}$ & No./plant & $\begin{array}{c}\text { Mean } \\
\text { wt } \\
(\mathrm{g}) \\
\end{array}$ & \\
\hline 17 June & 308 & 36 & 8.6 & 242 & 23 & 10.8 & 36 \\
\hline 27 June & 202 & 26 & 8.0 & 145 & 14 & 10.6 & \\
\hline 8 July & 163 & 17 & 9.9 & 135 & 12 & 11.1 & 2 \\
\hline 18 July & 177 & 15 & 11.6 & 156 & 12 & 12.9 & 21 \\
\hline Significance & $\mathrm{L}^{* *}$ & $\mathrm{~L}, \mathrm{Q} * *$ & $\mathrm{~L}^{* *}$ & $\mathrm{~L}, \mathrm{Q}^{* *}$ & $\mathrm{~L}, \mathrm{Q} * *$ & $\mathrm{~L} *$ & $\mathrm{~L}, \mathrm{Q}^{* *}$ \\
\hline
\end{tabular}

*,**Linear (L), quadratic $(\mathrm{Q})$, and significance at $P=0.05$ or 0.01 , respectively.

Table 5. Effect of WB and CB planting dates on yield and yield components of field-grown CSWB strawberry plants at Laval.

\begin{tabular}{|c|c|c|c|c|c|c|c|}
\hline \multirow[b]{2}{*}{$\begin{array}{l}\text { Planting } \\
\text { date } \\
\text { (WB, 1985) }\end{array}$} & \multirow[b]{2}{*}{$\begin{array}{c}\begin{array}{c}\text { Planting } \\
\text { date }\end{array} \\
(\mathrm{CB}, 1986)\end{array}$} & \multicolumn{3}{|c|}{ All berries } & \multicolumn{3}{|c|}{ Marketable berries } \\
\hline & & $\begin{array}{l}\text { Yield } \\
\text { (g/plant) }\end{array}$ & No./plant & $\begin{array}{c}\text { Mean } \\
\text { wt } \\
(\mathrm{g}) \\
\end{array}$ & $\begin{array}{c}\text { Yield } \\
\text { (g/plant) }\end{array}$ & No./plant & $\begin{array}{c}\text { Mean } \\
\text { wt } \\
(\mathrm{g}) \\
\end{array}$ \\
\hline \multirow[t]{2}{*}{17 June } & 15 May & 273 & 33.8 & 8.1 & 231 & 25.8 & 8.9 \\
\hline & 16 June & 139 & 19.6 & 7.9 & 121 & 15.9 & 8.5 \\
\hline \multirow[t]{2}{*}{27 June } & 15 May & 246 & 28.1 & 8.7 & 200 & 20.4 & 9.7 \\
\hline & 16 June & 131 & 17.3 & 7.5 & 114 & 13.7 & 8.3 \\
\hline \multirow[t]{2}{*}{8 July } & 15 May & 238 & 26.8 & 8.8 & 198 & 21.0 & 9.4 \\
\hline & 16 June & 137 & 16.0 & 8.5 & 119 & 12.9 & 9.2 \\
\hline \multirow[t]{2}{*}{18 July } & 15 May & 205 & 21.5 & 9.5 & 173 & 16.8 & 10.2 \\
\hline & 16 June & 137 & 13.7 & 10.0 & 120 & 11.0 & 10.8 \\
\hline \multicolumn{8}{|l|}{ Contrasts } \\
\hline WB linear $(1$ & May) & NS & $* *$ & $*$ & NS & 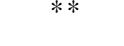 & $*$ \\
\hline WB linear (16 & June) & NS & $* *$ & $*$ & NS & $* *$ & $*$ \\
\hline CB (15 May & vs. 16 June) & ) $* *$ & $* *$ & $\mathrm{NS}$ & $* *$ & $* *$ & NS \\
\hline
\end{tabular}

$\mathrm{NS}, *, * *$ Nonsignificant or significant at $\mathrm{P}=0.05$ or 0.01 , respectively.

vegetative traits (Table 8). 'Bogota' was the most vigorous cultivar tested, attaining the highest value for each character measured, although the differences were not always significant. 'Bogota' had significantly more crowns (27\%) and leaves than the second ranking cultivar, Elvira. Generally, crown count per plant only ranged between 1.0 and 1.7, with 'Bogota' having the most. 'Raritan', which was the least vigorous cultivar tested, showed no significant increase in crown count during growth in the WB.

\section{Discussion}

The WB system has been proposed as a possible mechanism for season extension of strawberry by summer planting. It is composed of three phases, the two field phases, WB and $\mathrm{CB}$, where plants are produced and fruited, respectively, were examined in this study.

During the first or WB phase, the yield potential of the plant was established. In June-bearing strawberry, flower bud initiation (FBI) occurs during the late summer and fall under short days (> $14 \mathrm{~h}$ ) and low temperatures (Durner and Poling, 1988) and is the most important period in determining yield potential (Webb et al., 1974b). There are several factors that can contribute to optimal yield potential by enhancing FBI, including adequate moisture, sunlight, good nutrition, and large, healthy leaf area (Galletta and Bringhurst, 1990). Therefore, the largest, most vigorous plants produced from a long growing season in the WB were expected to have the highest yields. However, the results of the Laval field and greenhouse trials were conflicting regarding the importance of early establishment of the WB plants. Early establishment of WB produced plants with more leaf area, higher total dry weight, and larger crowns and resulted in higher yields in the greenhouse environment than later establishment. However, this yield advantage was not observed for either total or marketable yield in the Laval field trials. Yield of plants in 
Table 6. Effect of CB planting date and cultivar on yield components of field-grown CSWB strawberry plants at Cambridge.

\begin{tabular}{lccc}
\hline $\begin{array}{c}\text { Planting } \\
\text { date } \\
\text { (CB) }\end{array}$ & $\begin{array}{c}\text { Total yield } \\
\text { (g/plant) }\end{array}$ & $\begin{array}{c}\text { Total } \\
\text { no./plant }\end{array}$ & $\begin{array}{c}\text { Mean wt } \\
(\mathrm{g})\end{array}$ \\
\hline 8 May & 84.5 & 13.1 & 6.5 \\
16 June & 40.6 & 8.6 & 4.8 \\
10 July & 31.0 & 7.5 & 4.5 \\
1 Aug. & 16.9 & 3.5 & 4.2 \\
Significance & $\mathrm{L}^{* *}$ & $\mathrm{~L}^{* *}$ & $\mathrm{~L}^{*}$ \\
Cultivar & & & \\
Bogata & 41.3 & 6.5 & 5.5 \\
Elvira & 43.3 & 9.3 & 4.4 \\
Kent & 63.7 & 12.1 & 5.2 \\
Micmac & 44.2 & 7.3 & 5.9 \\
Raritan & 23.6 & 5.7 & 3.9 \\
SE & 12.7 & 2.0 & 0.3 \\
\hline
\end{tabular}

${ }^{*, * *}$ Linear $(\mathrm{L})$, quadratic $(\mathrm{Q})$, and significant at $P=0.05$ or 0.01 , respectively.

Table 7. Effect of $\mathrm{CB}$ planting date and cultivar on growth components of field grown CSWB strawberry plants at Cambridge.

\begin{tabular}{lcccc}
\hline & \multicolumn{4}{c}{ Growth component } \\
\cline { 2 - 5 } $\begin{array}{l}\text { Planting } \\
\text { date (CB) }\end{array}$ & $\begin{array}{c}\text { Plant } \\
\text { vigor }^{2}\end{array}$ & Trusses/plant & Flowers/plant & $\begin{array}{c}\text { Aborted } \\
\text { flowers } \\
\text { (\%/plant) }\end{array}$ \\
\hline 8 May & 4.6 & 2.2 & 19.3 & 32 \\
16 June & 4.5 & 1.8 & 11.1 & 23 \\
10 July & 4.9 & 2.1 & 12.1 & 38 \\
1 Aug. & 5.1 & 2.1 & 11.7 & 70 \\
Significance & $\mathrm{L}^{*}$ & NS & $\mathrm{L}^{* *} \mathrm{Q}^{*}$ & $\mathrm{Q}^{*}$ \\
Cultivar & & & & \\
Bogata & 5.1 & 2.1 & 10.8 & 49 \\
Elvira & 5.4 & 2.7 & 17.8 & 43 \\
Kent & 4.6 & 2.1 & 16.9 & 28 \\
Micmac & 4.6 & 2.0 & 12.4 & 40 \\
Raritan & 0.4 & 1.3 & 9.8 & 42 \\
SE & 0.4 & 0.4 & 3.0 & 3.7 \\
\hline
\end{tabular}

${ }^{2}$ Plant vigour was measured as the amount of leaf area present on a visual scale where $1=$ dead and $6=$ a vigorous plant with $10+$ leaves.

${ }^{y}$ Percent aborted flowers $=($ flower no. - total berry no. $)$ /flower no. $\times 100$.

Ns,*,**Nonsignificant or significant at $P=0.05$ or 0.01 , respectively. Linear (L), quadratic (Q).

Table 8. Vegetative growth of five strawberry cultivars established in WB at Cambridge 86 days after planting on 14 Aug.

\begin{tabular}{lcccccc}
\hline & \multicolumn{2}{c}{ Leaf } & & \multicolumn{2}{c}{ Crown } & Root \\
\cline { 2 - 3 } \cline { 5 - 6 } Cultivar & No./plant & $\begin{array}{c}\text { Dry wt } \\
\text { (g/plant) }\end{array}$ & & No./plant & $\begin{array}{c}\text { Diam } \\
(\mathrm{mm})\end{array}$ & $\begin{array}{c}\text { Rry wt } \\
(\mathrm{g})\end{array}$ \\
\hline Bogata & $9.8 \mathrm{a}^{\mathrm{z}}$ & $3.5 \mathrm{a}$ & & $1.7 \mathrm{a}$ & $14.4 \mathrm{a}$ & $3.0 \mathrm{a}$ \\
Elvira & $7.7 \mathrm{~b}$ & $3.4 \mathrm{a}$ & & $1.3 \mathrm{~b}$ & $14.0 \mathrm{ab}$ & $1.9 \mathrm{ab}$ \\
Kent & $5.1 \mathrm{c}$ & $2.1 \mathrm{ab}$ & & $1.2 \mathrm{~b}$ & $12.2 \mathrm{abc}$ & $2.2 \mathrm{ab}$ \\
Micmac & $4.6 \mathrm{c}$ & $2.2 \mathrm{ab}$ & & $1.1 \mathrm{~b}$ & $11.6 \mathrm{bc}$ & $1.7 \mathrm{~b}$ \\
Raritan & $4.6 \mathrm{c}$ & $1.7 \mathrm{~b}$ & & $1.0 \mathrm{~b}$ & $10.3 \mathrm{c}$ & $1.2 \mathrm{~b}$ \\
\hline
\end{tabular}

${ }^{2}$ Mean separation by Duncan's multiple range test, $P=0.05$.

WB set 18 July were $25 \%$ lower than those of the 15 June planting, although the yield decline was not significant. Plants of WB established in mid-August at Cambridge, using current season's runners, were much smaller than plants at Laval and demonstrated very little relative yield potential in the B. There does appear to be a threshold time for planting date, with higher yield potential being favored by earlier planting.

When considering the maximization of yield potential within the WB, careful consideration must be given to optimization of correlated vegetative characters and yield components. Leaf count and area of strawberry are closely associated with establishment of yield potential and fruiting the following season (Morrow and Darrow, 1940; Sproat et al., 1936). Crown and leaf dry weight are also related to higher yield on a per-plant basis (Strik and Proctor, 1988). Although these characters are important to yield, photosynthesis per se during FBI has not been related to the following season's yield, but mechanisms have been identified whereby photosynthesis did contribute to yield in high and low yielding strawberry genotypes (Strik and Proctor, 1988). Carbohydrate partitioning within the plant and net carbon accumulation. may be more important than actual photosynthetic rates; hence, the importance of leaf characters to yield.

CNO is an important yield component in the WB plants because runners are removed and each crown cap be a potential site for floral initiation. CNO has been identified as an important yield component by the other researchers (Olsen et al., 1985; Webb et al., 1974b). CNO has also been negatively correlated with berry weight (Galletta and Bringhurst, 1990) and was not a useful character to predict yields of various genotypes (Strik and Proctor, 1988). The low yield potential of single crown plants was confirmed in Cambridge and in a trial in England planted with single crown plants that yielded 90 to $100 \mathrm{~g} / \mathrm{plant}$ (Royle, 1985). The author attributed the poor performance to failure to produce an adequate number of flowers. The August WB planting had insufficient leaf area, dry weight, and vigor to support optimal flower bud differentiation. The importance of timely WB planting has been demonstrated in Holland where yield is reduced when planting of freshly dug or cold-stored runner plants is delayed after 10 Aug. or 10 July, respectively (Burgess, 1986).

During the WB phase, deblossoming and runner removal are standard practices (Baumann and Daubeny, 1989). Runners and inflorescences are major dry weight sinks during strawberry establishment (Forney and Breen, 1985; Strik and Proctor, 1988) and their removal facilitates reallocation of carbohydrates to leaves and crowns. Deblossoming stimulates an increase in leaf area (Forney and Breen, 1985), which offsets any decrease in carbohydrate produced due to a decrease in net photosynthesis (Forney and Breen, 1985; Schaffer et al., 1986). Developing fruit are also very strong sinks (Forney and Breen, 1985; Olsen et al., 1985) and their early removal permits carbohydrates destined for flower and fruit development to be available within the mother plant for other organs such as roots and crowns. Runner production can account for $>50 \%$ of total plant dry weight (Strik and Proctor, 1988) and place a stress on the mother plant for carbohydrates.

The June-bearing strawberry is adapted and responds to cool to moderate weather (Durner and Poling, 1988), which is the typical climate experienced in most areas during flowering and fruiting. However, season extension techniques, such as the $\mathrm{WB}$, require the strawberry to flower and fruit under a greater range of environments, including high summer temperatures. In strawberry, the problems associated with high temperature stress include the inhibition of fruit weight and size above $35 / 25 \mathrm{C}$ (day/night) and lowering of quality (as measured by mean soluble solids concentration) above 25/15C (Hellman and Travis, 1988). High root zone temperature has also been related to smaller fruit size in day neutrals, and optimal fruit development occurs 
when root temperatures are low $(\approx 7 \mathrm{C})$. In the northern United States and southern Ontario, extended periods of high summer temperatures are very common most years. There was no cultivar $\times \mathrm{CB}$ planting date interaction, indicating cultivars responded similarly to the different environments of the four planting dates. However, yields decreased $43 \%$ at Lava1 and $52 \%$ at Cambridge between the May and June CB dates, respectively, presumably mainly because of the increasing air and soil temperatures during each growing period. The decline in yield as planting dates became later has been observed in other summer planting studies (Moore and Bowden, 1968).

Later CB plantings were generally associated with small berries and a high percentage of fruit abortion. Although fruit size potential is determined in the previous fall by the potential total number of achenes per fruit (Abbott et al., 1970), final berry size depends on the final number of achenes and the degree of expansion of the surface, which is determined during berry development (Abbott et al., 1970; Dana, 1980; Mudge et al., 1981; Webb et al., 1974a). Therefore, the expression of the potential berry size is affected by environmental factors (Webb et al., 1973) such as extreme temperature and water stresses, cultivar (Webb et al., 1978), or scarcity of pollinators (Pion et al., 1980). The low yield of July-CB at Lava1 and the failure of the August-CB at Cambridge were at least partially due to the early killing frost (26 Sept.) that ended production and the abnormally high levels of precipitation during September, respectively. Cool, moist weather reduces normal pollen germination (Dana, 1980) and good fruit set (Baumann and Daubeny, 1989).

Baumann and Daubeny (1989) found no difference between six CB planting dates ranging between mid-May and mid-July in southern British Columbia. The Pacific Northwest experiences a much more moderate climate than the northeastern United States and southern Ontario without some of the extremely high, stressful temperatures of the East. High temperatures and the stress imposed on the plants, even when well watered, are limiting factors that must be addressed. Due to high temperatures during CB establishment, leaf production and flower emergence are enhanced while, as noted, root growth is inhibited. Uses of mulches to lower soil temperatures and intermittent misting to reduce transpiration losses may promote more rapid root development and reduce moisture stress on the plant. The soil type at the Cambridge Research Farm was a Fox sandy loam with poor water-holding capacity, which contributed to the poor yields at this location, especially at the later planting dates. Galletta and Bringhurst (1990) discuss the attributes of different soil types for strawberry production and indicate that deep, fertile, sandy loams are optimal. Soil type may be an important consideration for the WB technique.

During the WB phase, the production of a healthy plant with high-yield potential capable of successful cold storage is the main objective. High yield potential can be established through the interaction of several yield components. Galletta and Bringhurst (1990) discuss yield component analyses and present several correlations between vegetative and reproductive components in strawberry. Strik and Proctor (1988) used yield component analysis to differentiate high and low yielding cultivars in Ontario. Interpretation of the correlations produced from these studies indicates that fruit size and fruit count are positively correlated with number of inflorescences, leaves, and crowns and a "medium" crown density. In contrast, fruit and inflorescence counts were negatively correlated with runner weight and leaf and plant size. In our study, CNO was positively correlated with FLNO per plant, TCO, total yield, and total berry counts. However, CNO was negatively correlated with marketable berry weight. Earlier planting into the WB resulted in more crowns, larger and more leaves, and a higher root dry weight, all of which contributed to higher yielding plants in the CB. In this study, the positive correlations between $\mathrm{CNO}$ and other yield components outweighed any negative associations that may have been present. If CNO per plant increases dramatically, these correlations may not remain as high.

The importance of reserve storage capacity (RSC) as defined by CNO $\times$ crown diameter (Galletta and Bringhurst, 1990) to yield potential must also be considered for the WB system. RSC for the 17 and 27 June, 8 and 18 July WB planting dates was 52, 49, 32, and 40, respectively. Forney and Breen (1985) determined sink strength was greater than source capacity in a fruiting strawberry plant and the deficit would be obtained from other plant organs. Low RSC may have partially contributed to the low yield potential of the August-planted WB at Cambridge (compared with Laval). At Cambridge, plants with small leafareas would be unable to supply enough carbohydrates for optimal root development, flower bud initiation, and RSC.

The highest yield obtained in this study was $273 \mathrm{~g} /$ plant with three-crowned 'Kent' plants at Laval. In comparison, 'Kent' at Cambridge produced only $109 \mathrm{~g} /$ plant. 'Rainer' produced a maximum yield of $247 \mathrm{~g} / \mathrm{plant}$ with eight crowns per plant in British Columbia WB trials (Baumann and Daubeny, 1989). The similarity in yield and difference in CNO number implies that there may be an optimum number of crowns per plant or other yield components in WB. Baumann and Daubeny's (1989) and our study indicate that cultivars differ in adaptability to the WB and $\mathrm{CB}$ phases of this technique. Cultivars differ in their vegetative growth characters in the WB and, therefore, establish different yield potentials for the CB. For instance, some cultivars have a greater ability to form multiple crowns than others. In both locations (i.e., British Columbia and Ontario), there was about a 3-fold difference in yield between the highest and lowest yielding cultivars in the trials. Selecting cultivars for this technique based on matted-row trials is not appropriate because interplant competition common in the matted-row system is greatly reduced in the WB system.

The economic potential of the WB system appears to be positive. Feasibility studies in Great Britain (Burgess, 1986) determined that a yield of $103 \mathrm{~g} /$ plant was the economic threshold. This and a study in the Pacific Northwest (Baumann and Daubeny, 1989) confirm that this threshold value can be obtained and exceeded by $>2$-fold. Economic potential could be further enhanced by allowing the $\mathrm{CB}$ plants to fruit a second season to reduce plant and establishment costs (Baumann and Daubeny, 1989).

Future work is required to determine optimal yield components such as CNO for several cultivars and to optimize yields during the warmer summer months.

\section{Literature Cited}

Abbott, A.J., G.R. Best, and R.A. Webb. 1970. The relation of achene number to berry weight in strawberry fruit. J. Hort. Sci. 46:215222.

Baumann, T.E. and H.A. Daubeny. 1989. Evaluation of the waitingbed cultural system for strawberry season extension in British Columbia. Adv. Strawberry Prod. 855-57.

Burgess, C. 1986. New techniques which can realize better yields in a longer season. Grower 106:24-26.

Craig, D.L. and G.L. Brown. 1977. Influence of digging data, chilling, 
cultivars and culture on greenhouse strawberry production in Nova Scotia. Can. J. Plant Sci. 57:571-576.

Dana, M.N. 1980. The strawberry plant and its environment, p. 3344, In: N.F. Childers, (ed.). The strawberry. Horticultural Publications, Gainesville, Fla.

Daubeny, H.A. 1980. Strawberry production trends in Canada, p. 2130. In: N.F. Childers (ed.). The strawberry. Horticultural Publications, Gainesville, Fla.

Durner, E.F. and E.B. Poling. 1988. Strawberry developmental responses to photoperiod and temperature: a review. Adv. Strawberry Prod. 7:6-15.

Forney, C.F. and P.J. Breen. 1985. Dry matter partitioning and assimilation in fruiting and deblossomed strawberry. J. Amer. Soc. Hort.

Sci. 110:181-185.

Galletta, G.J. and R. Bringhurst. 1990. Strawberry management, p. 83-156. In: G.J. Galletta and D.G. Himelrick (eds.). Small fruit crop management. Prentice-Hall, Englewood Cliffs, N.J.

Hellman, E.W. and J.D. Travis. 1988. Growth inhibition of strawberry at high temperatures. Adv. Strawberry Prod. 7:36-38.

Leblanc, M, Y. Desjardins, R. Bedard and A. Gosselin. 1987. The effects of blossom removal on production characteristics of dayneutral strawberry plants grown in a Northern climate. Adv. Strawberry Prod. 6:23-26.

Moore, J.N. and H.L. Bowden. 1968. Response of strawberry varieties to date of planting in Arkansas. Proc. Amer. Soc. Hort. Sci. 91:231235.

Morrow, E.B. and G.M. Darrow. 1940. Relation of number of leaves in November to number of flowers the following spring in the Blackmore strawberry. Proc. Amer. Soc. Hort. Sci. 37:571-573.

Mudge, K. W., K.R. Naryanan, and B.W. Poovaiah. 1981. Control of strawberry fruit set and development with auxins. J. Amer. Sot. Hort. Sci. 106:80-84.

Olsen, J., L.W. Martin, P.J. Pelofske, P.J. Breen, and C.F. Forney. 1985. Functional growth analysis of the strawberry. J. Amer. Sot. Hort. Sci. 110:89-93.

Pion, S., D. De Oliveira, and R.O. Paradis. 1980. Agents pollinisateurs et productivity du fraisier 'Redcoat', Fragaria x ananassa Duch. Phytoprotection 61:72-78.

Royle, D. 1985. Low yields cast doubt on UK use of waiting bedplants. Grower (June) 105:13.

Schaffer, B., J.A. Barden, and J.M. Williams. 1986. Net photosynthesis, dark respiration, stomatal conductance, specific leaf weight,

and chlorophyll content of strawberry plants as influenced by fruiting. J. Amer. Soc. Hort. Sci. 111:82-86.

Sproat, B.B., G.M. Darrow, and J.H. Beaumont. 1936. Relation of leaf area to berry production in the strawberry. Proc. Amer. Sot. Hort. Sci. 33:389-392.

Strik, B. and J.T.A. Proctor. 1988. Yield component analysis of strawberry genotypes differing in productivity. J. Amer. Soc. Hort. Sci. 113:124-129.

Webb, R. A., B.A. White, and R. Ellis. 1973. The effect of rooting date on fruit production in the strawberry. J. Hort, Sci. 48:99-110.

Webb, R.A., J.V. Purves, and B.A. White. 1974a. The components of fruit size in strawberry. Scientia Hort. 2: 165-174.

Webb, R. A., J.V. Purves, B.A. White, and R. Ellis. 1974b. A critical path analysis of fruit production in strawberry. Scientia Hort. 2:175184.

Webb, R.A., J.H. Terblanche, J.V. Purves, and M.G. Beech. 1978. Size factors in strawberry fruit. Scientia Hort. 9:347-356. 